"Value chain analysis to improve corporate performance: a case study of essential oil export company in Indonesia"

\begin{tabular}{ll} 
AUTHORS & $\begin{array}{l}\text { Sutarmin } \\
\text { Dadang Prasetyo Jatmiko }\end{array}$ \\
\hline ARTICLE INFO & $\begin{array}{l}\text { Sutarmin and Dadang Prasetyo Jatmiko (2016). Value chain analysis to improve } \\
\text { corporate performance: a case study of essential oil export company in } \\
\text { Indonesia. Investment Management and Financial Innovations, 13(3-1), 183-190. } \\
\text { doi:10.21511/imfi.13(3-1).2016.04 }\end{array}$ \\
\hline DOI & http://dx.doi.org/10.21511/imfi.13(3-1).2016.04 \\
\hline RELEASED ON & Friday, 23 September 2016 \\
\hline JOURNAL & "Investment Management and Financial Innovations" \\
\hline FOUNDER & LLC "Consulting Publishing Company "Business Perspectives" \\
\hline NUMBER OF REFERENCES &
\end{tabular}

(C) The author(s) 2023. This publication is an open access article. 


\title{
Value chain analysis to improve corporate performance: a case study of essential oil export company in Indonesia
}

\begin{abstract}
The purpose of this paper is to analyze the value chain, the main activities, and supporting activities as well as cost driver activity of one essential oil export company in Central Java. This research is a case study using the survey method (ex post facto). Primary data were collected by in-depth interviews and FGD (Focus Group Discussion). Secondary data were taken from natural materials purchasing department and finance department and controlling. Based on the research, the authors found that the main activity of the company consists of Supply, Purchasing/Procurement, Production Planning, Manufacturing, Materials, Quality Control (QC), Research and Development (R \& D), Sales and Marketing and Customer activities. While supporting activities (support) consist of Personal and General Affair (P \& GA), Information Technology (IT), Administration, Quality Assurance (QA) and Maintenance activities. Based on the value chain analysis (VCA), the company has Purchasing and R \& D activities as the main activity of which is a characteristic that distinguishes the generic value chain of Porter. Purchasing a company with a cost driver activity expenditure composition of $85.6 \%$. Clove oil is the dominant raw material of $78.26 \%$.

Based on this research, the authors, then, put forward some suggestions as follows: firstly, doing further research with the identification and analysis of internal and external factors, in order to know the internal strengths and weaknesses, opportunities and threats faced by the company. Second, analyzing company's competitive position and the selection of alternative strategies to formulate strategies that can enhance the competitive advantage of companies.
\end{abstract}

Keywords: value chain analysis, main activity, supporting activity, cost driver.

JEL Classification: M21, M41.

\section{Introduction}

Competition is the core of the success or failure of a company. Competition determines the accuracy of the company's activities that reinforce its performance, such as innovation, cohesive culture or good implementation (Porter, 2008). Companies should focus on competing against economies of scale, high production volume, broad economic sphere, as well as increasing agility in offering the products (Bennett and Forrester, 1993). Competitive advantage should be seen as a dynamic process and not just the final product (Cravens, 1996). This dynamic process must be managed effectively not only to produce, but also the entire chain of business activities, both chains of raw materials preparation and the final value given to the customer (Christopher, 2005).

To enhance the competitive advantage, the company should have effective and efficient management. The effectiveness of management can be measured by how big the target is achieved compared with the target set by a company. The efficiency of management can be measured by comparing the costs and time. The best company is placed to create value and market opportunities when there is an effective combination of supply chain and maximize the overall value chain of companies (Walter, 2004).

(C) Sutarmin, Dadang Prasetyo Jatmiko, 2016.

Sutarmin, Ph.D. Candidate from Universitas Jendral Soedirman, Indonesia and Lecturer at Universitas Peradaban, Indonesia. Dadang Prasetyo Jatmiko, Auditor at Badan Standardisasi Nasional Indonesia.
It would be a distinct advantage if the supply chain succeeds in analyzing the value at each step, identifying the alignment, effectively capturing the attributes that consumers want and adjusting the chain of products and processes on the consumer's needs (Zokaei and Simons, 2006).

Competitive advantage has stage process consisting of a source of excellence, excellence positions and final achievement, as well as investment income to maintain the advantage. Porter (2008) stated that every company is required to increase the competitive advantage in the global trading system. In achieving competitive advantage, the operations manager can perform three main things, namely, differentiation, and leadership to cost and response (Heizer and Render, 2006). Competitive advantage can be manifested through a competitive advantage on the distinction, competing on cost, namely, competing on low cost and competitive advantage through the response, i.e., flexible, reliable and fast response.

To achieve competitive advantage, we need the right competitive strategy. Competitive strategy is often called as business strategies that focus on improving the competitive position of products and services (Hunger and Wheelen, 2001). Competitive strategy is the search for a favorable competitive position in an industry. Competitive strategy aimed at enforcing a favorable position against the strengths that determine industry competition. Competitive strategy is not only a response to the environment, but also an effort to establish the environment in accordance with the wishes of the company (Porter, 
1985). Value chain management (VCM) involves collaborative allocation of resources, within and between the respective businesses in the chain to provide added value at a lower cost and at a faster rate than competitive supply chains. Collaborative relationships facilitate the flow of information (both inbound and outbound), as well as products and services (Lee et al., 2007).

In manufacturing companies, there are four strength factors, namely, the delivery, value, flexibility, and innovation (Vickery et. at., 1997). In a complex and dynamic environment today, the creation of value for all stakeholders is not an easy task. In any attempt to value creation, management needs to understand the dynamic features of the company's value system (Hasan, 2010). There are four elements of the value chain in implementing the competitive strategy, namely, marketing, research and development, procurement, and operations related to product quality and product innovation.

Porter (1985) argues that a company's business is best described as value chain. Managers can win the competition by targeting elements of the value chain through their company for a specific purpose (Prajogo et al., 2008). A company might benefit if total revenues exceed total costs resulting from the creation and delivery of products or services. Companies should not only understand their own value chain operations, but also the value chain of competitors, suppliers, and distributors. The combined cost of all activities in the company's value chain determines the cost incurred by the company to run its business. Value chain analysis can be very important for companies to monitor whether the prices and costs are competitive. The value chain is very different between industries and companies. Companies must determine whether the strengths and weaknesses within its value chain costs occur relative to the value chain of rival firms. The value chain activities that are able to run very well by the company is a core competence. When the core competency develops into a major competitive advantage, then, it is called a distinctive competence. Consumer value associated with certain activities is related to the activities of each stage of the supply chain (Soosay, Fearne and Dent, 2012).

One company that continues to develop in order to always have an effective and efficient management is manufacturing and exporting company in Central Java, Indonesia. The company management is presently focusing on the financial statements presented by the Department of Finance and Controlling regardless of the value chain of any company's activities being carried out. In these conditions, the strength and weaknesses, as well as activities as cost drivers and core competencies are not known clearly and deeply. With the unclear cost driver or core competence of the company, it is possible that the company can make or formulate less precise short-term and long-term strategies.

Based on the background research problems presented upfront, then, the formulation of the research questions is: (1) How is the value chain model owned by the company today? (2) What are the activities that become the main activities of the company? (3) What are the activities that become the supporting activities of the company? (4) What are the activities that become the cost driver or the core competence of the company?

\section{Theoretical background}

The value chain analysis (VCA) provides a rational and systematical framework to describe and evaluate the role and relationship of people and organizations (Bolwig et al., 2010; Rushton, 2009). This includes understanding the material flow and added value activities between different parts of the value chain (Rushton, 2009). The value chain analysis is also made up of people as the main focus that allows an understanding of their role, motivation and behavior in the context of the cultural, social, economic and other drivers (Irvine, 2015). The role of motivation and behavior of people in the value chain can be understood by considering the cultural, economic and social beliefs and personal needs (Rushton and Leonard, 2009). Regardless of the complexity of the VCA, the analysis procedure can be done by applying the following procedure: first, the operation process of a company is divided into various activities or specific business processes; second, analysts are trying to charge on each activity and the costs can be in the form of time and money. Third, analysts change the cost data into information that may result in competitive advantages or disadvantages.

The value chain is characterized as collaborative and interdependent, including the internal company's business and external environmental policies (FAO, 2011; Porter, 1985). This extends the principles of supply chain focusing on promoting materials and downstream products from suppliers and realizing capital flows from the upstream (Mangan et al., 2012). Value chain analysis (VCA) refers to the process by which a company determines the cost associated with the activities of the company from the purchase of raw materials to the production and marketing. VCA aims to identify where the advantages or disadvantages of existing low cost throughout the value chain. Michael E. Porter (2008) developed an approach to analysis tools called as value chain analysis. This approach is the systematic way of looking at the company serve its customers. Value chain analysis is shown in Figure 1. 


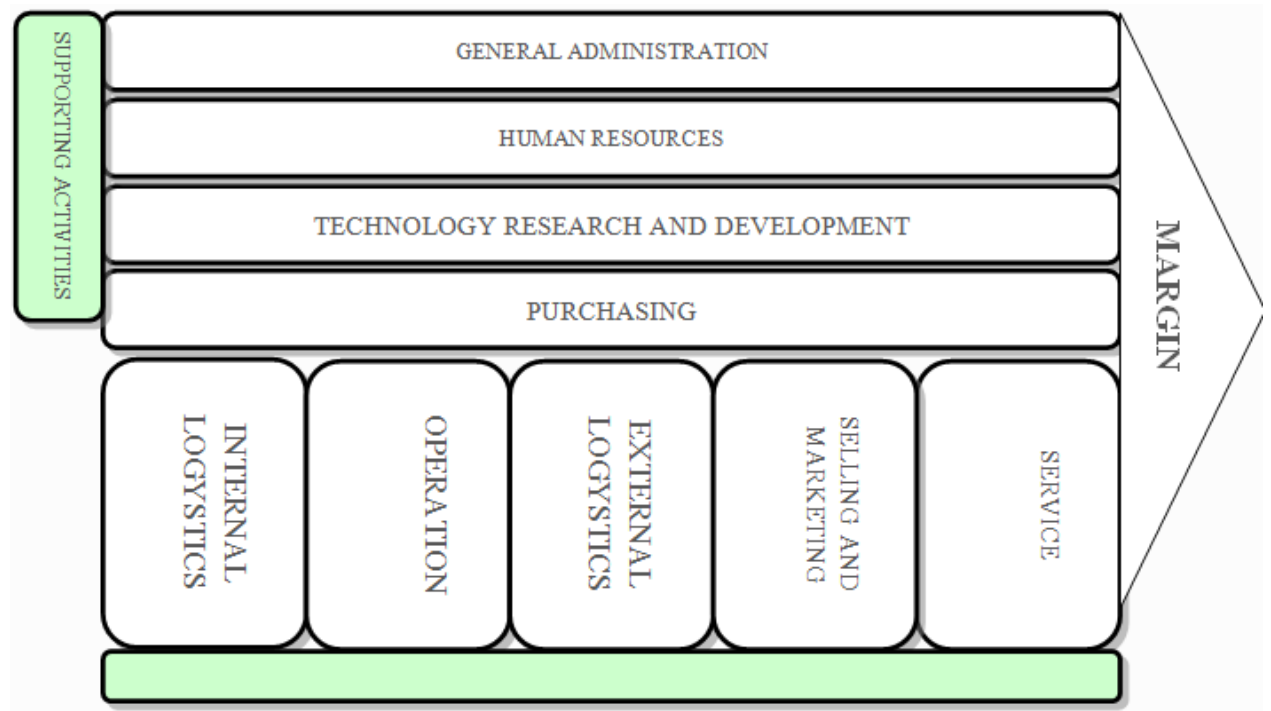

Source: Michael E. Porter (2008). Competitive Advantage.

Fig. 1. Generic value chain of Porter

According to Porter (2008), the basic categories of the value chain are grouped into two general groups, namely, main activities and supporting activities. The main activities include the physical creation, marketing, delivery and after sales support of products or services. The main activity consists of five categories, namely, internal logistics, operation, external logistics, marketing and sales, as well as service, while supporting activities include the provision of infrastructure or inputs that allow the main activities taking place continuously. Supporting activities include purchasing, technology research and development, public administration and human resource management.

Value change analysis (VCA) can enable a description of the important people, the path and the current relative value chain, allowing strengths and gaps to be identified, prioritization of resources and the basis for participation in the activities of the value chain (Hartwich et al., 2005). VCA enables the understanding of the behavior of people and, therefore, their decision-making, which can lead to changes in the activity and the risk profile of the value chain (Rushton et al., 2009).

VCA is a tool to check the current state of chain and identify better future state (Jones and Womack, 2002). VCA can also be applied in the concept of waste minimization and efficiency of material flow which contains additional features such as the strength of inter-organizational relationships (Taylor, 2005). VCA is able to identify the broader and more relevant dimensions in the business scenario in which there is a growing importance to include social and environmental impacts into the "mainstream" business strategy (Fearne, Garcia Martinez and Dent, 2012). The value chain analysis can help companies to define and pursue their competitive advantages (Anderson and Elloumi, 2004).

\section{Methodology}

This research is a case study using survey method (ex post facto). The study was conducted in one of the manufacturing and exporting company in Central Java, Jakarta and West Java in Indonesia.

Sources of data in this study are secondary and primary data. Secondary data were obtained from an existing internal data and collected by the Department of Natural Product Buying, Department of Finance and Controlling, as well as the Central Document. Secondary data that would be taken are primarily financial data of company, the quantity of purchase, purchase price, quality procedures and quality manual. External secondary data were obtained from outside the company, for example, the Central Bureau of Statistics, in particular the expo data. In addition to secondary data, this study also collected primary data directly from the respondent/informant. Primary data were collected by in-depth interviews (depth interview) and FGD (Focus Group Discussion) against officials who have professional competence in the field, namely, Vice President Director, Directors and Managers and purchase staff.

\section{Data analysis}

Once the data were selected (sorted) and collected in accordance with the purpose of research, we, then, analyzed the data. From primary and secondary data obtained, the analysis of the value-chain was done with three stages (Anderson and Elloumi, 2004):

a. Identifying the value chain activities. Value chain activities must be identified to see and describe how to map the value chain. 
b. Determining the strategic activities. This step is to identify the activities where the company has the advantages of both current and potential advantages.

c. Tracing the cost of the activity and determining cost drivers on strategic activities. Cost drivers are factors that change the amount of the total cost. Therefore, the aim at this stage is to identify the activities where the company has a cost advantage of both current and potential cost advantages.

d. Developing a competitive advantage by reducing the costs or adding the value. At this stage, the nature of the potential competitive advantage is determined by studying the activity of the value and cost drivers identified above.

\section{Result}

\section{Mapping and identification of value chain activities}

Manufacturing and exporting company in Central Java is part of a group of companies engaged in manufacturing or fabrication. Two other companies are engaged in trading and as the Holding Company. To obtain an overview of the value chain activities, the company has carried out a series of data collection and in-depth interviews on the informants. The informants involved are the staff of Purchasing and the Senior of Manager Purchasing. Data collection and summary of information collected from informants are outlined in the form of chart of value chain on main activities and supporting activities. The company's main activities consist of Purchasing/Procurement, Production Planning, Manufacturing, Material, Quality Control (QC), Research and Development ( $R \& D$ ), as well as Sales and Marketing activities.

Supporting activities consist of Personal and General Affair (P \& GA), Information Technology (IT), Admintration, Quality Assurance (QA) and Maintenance activities. The value chain of each functional activity is described as follows:

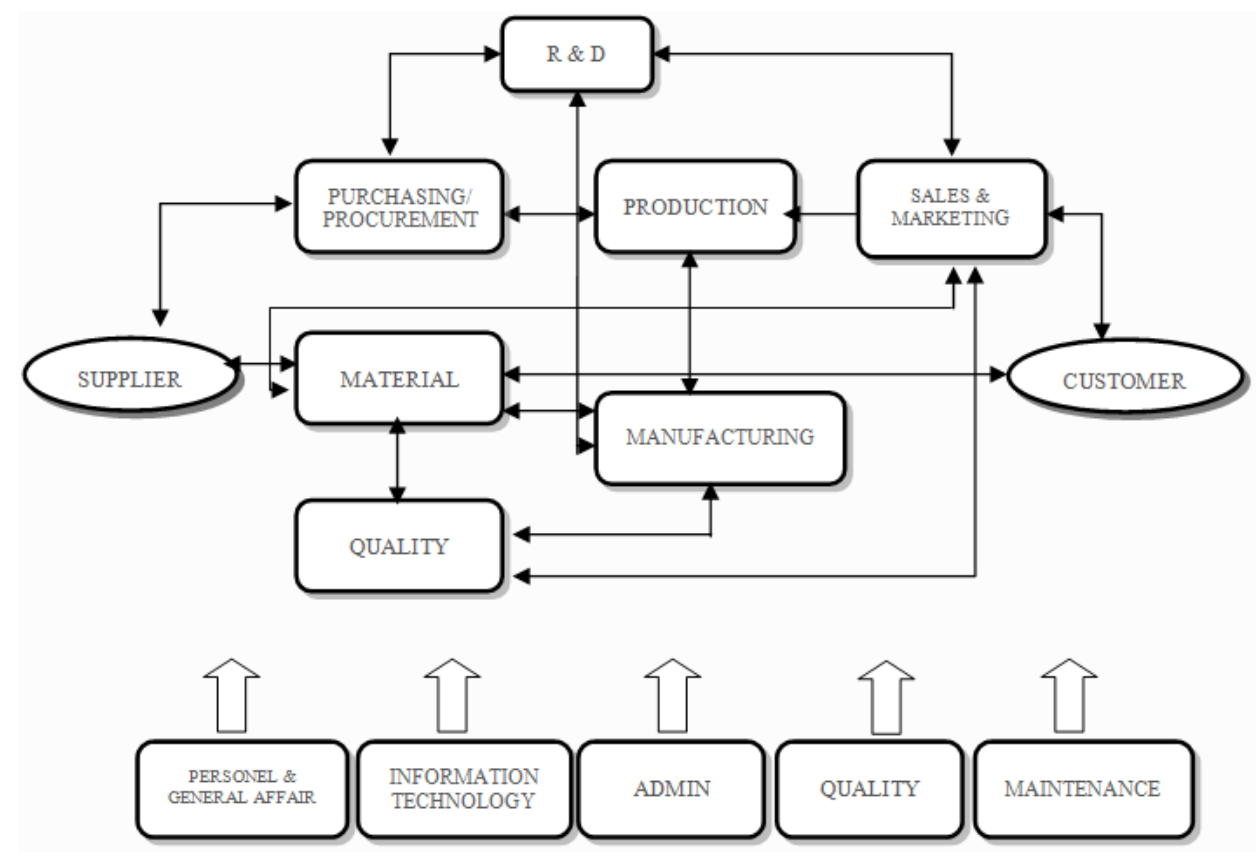

Source: prepared for the study.

Fig. 2. Functional value chain of a company

Figure 2 shows the functional value chain of a company as the results of depth interview study. Furthermore, each of the above functional activity is further divided into activities forming a chain of derivatives activity. There are two basic categories of activity, namely, main activities and supporting activities. Each basic category is, then, breakdown again become more detailed activity.

\section{Main activities}

Sales and marketing. These activities include the following activities: offering product and price to the customers, confirming the PO (purchase order) from the customer, along with the technical department (QC, QA, R \& D, Manufacturing), dealing with customers' complaints, measuring customer satisfaction, receiving requests and requirements of new products from the customers. The next activity is forwarding the request and requirements of new products from the customers to the Department of $\mathrm{R} \& \mathrm{D}$, providing a forecast of material requirements to the Production Planning, providing SO/DO (Sales Order / Delivery Order) to the Department of Materials, asking QC department to sent a lot of samples to customers, conducting competitor analysis, promoting new products and 
conducting work analysis and continual improvement.

Production/operation (manufacturing department). These activities include the following activities: receiving Planned Order from Production Planning, sending the reservation/request of material to the Warehouse/Department of Materials, performing the production process according to the applicable SOP/work instructions, checking products in process and final product to the QC, conducting the process of experimental batch together with $\mathrm{R} \& \mathrm{D}$ and work analysis and continual improvement.

Research and Development (R\&D). These activities include the following activities: receiving requests and requirements of new products, designing new products that meet the requirements, upscalling or experimental batches along with the production, conveying to purchasing if a material for upscalling or experimental batches is needed, conducting the work analysis and continual improvement.

Production planning. These activities include the following activities: receiving and analyzing the forecast from Sales and Marketing, running MRP (Material Requirement Planning) to generate PR (purchase requisition) to Purchasing and Procurement, running MRP (Material Requirement Planning) to generate the Planned Order the production, allocating raw material needs to the Department of materials, controlling the final product and carrying out the work analysis and continual improvement.

Purchasing/procurement. These activities include the following activities: receiving Purchase Requisition from R\&D (for development) and from Production Planning, conducting vendor selection, requesting the offer and negotiating the price to the Supplier/Vendor, sending PO (Purchase Order) to the Supplier/Vendor, carrying out visit and transactions to the Supplier/Vendor, evaluating the performance of the Supplier/Vendor, returning the items that do not meet the requirements of the Supplier/Vendor, providing information to warehouse to be entered, reschedulling the arrival of raw materials, conveying the need of funds to the Finance/Accounting, training the vendors and doing the work analysis and continual improvement.

Materials activities. These activities include the following activities: receiving SO/DO from Sales and Marketing, sending the product to the Customer, allocating raw material in accordance with the Planner's request, receiving goods from suppliers according to PO, storing and controling raw materials and products, sending raw materials to order/reservation of production, proposing the raw materials inspection to QC, controlling the transport activities and conducting work analysis and continual improvement.

Quality control. These activities include the following activities: sending a lot of samples at the request of Sales and Marketing, checking out the Raw Materials, checking the Product in process and Final product and analysis work and continual improvement.

\section{Supporting activities}

In addition to main activities, supporting activities are also done with the detailed activities as follows:

Personnel and general affairs. These activities include the following activities: recruiting new employees, developing employees, coordinating the assessment of employees, dealing with safety and licensing, conducting environmental control, serving customers and conducting work analysis and continual improvement.

IT (Information Technology). These activities include the following activities: maintaining software and hardware bused, controlling database and application program, conducting work analysis and continual improvement.

Quality assurance. These activities include the following activities: ensuring that the process is in accordance with applicable standards, managing the customer complaints properly, making sure that the new products meet all the requirements, coordinating settlement deviation of product or process and conducting work analysis and continual improvement.

Maintenance. These activities include the following activities: performing maintenance machinery and equipment, repairing machinery and equipment, building/holding machinery and equipment required and creating a budget plan procurement of machinery and equipment.

Administration (finance and accounting). These activities include the following activities: supporting the provision of finance and investment, recording and documenting all activities of the company.

To see the correspondence between the generic value chain of Porter and the company value chain, a model that approaches the value chain of Porter chart is created as in Figure 1. The results of the manufacturing value chain model to look at the suitability based on Figure 1 and Figure 2 produce Figure 3 as follows: 


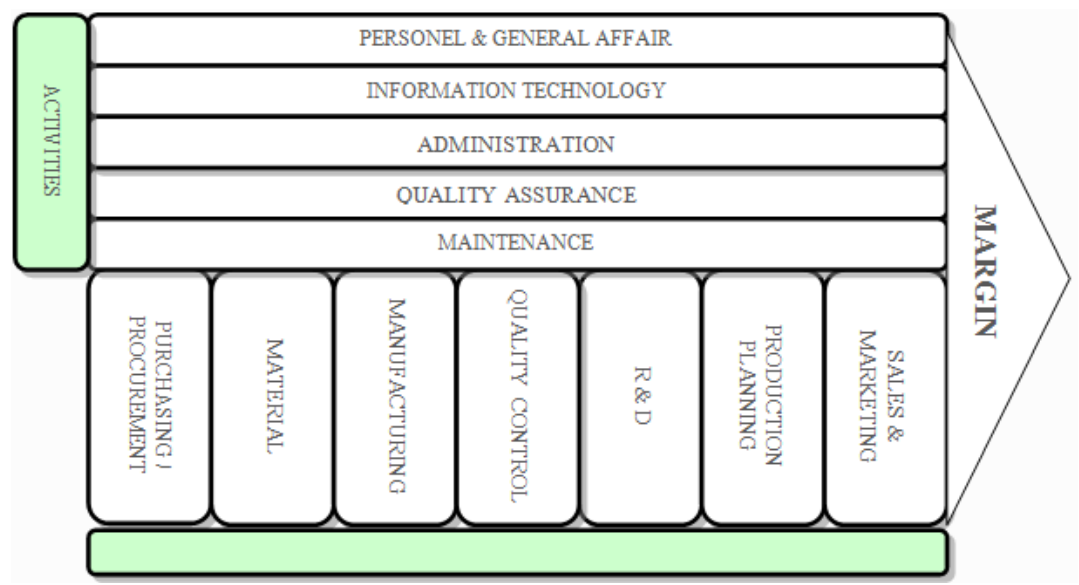

Source: prepared for this study.

Fig. 3. Value chain of functional activities of a company

Based on the figure above, it appears that the value chain activities undertaken by the companies differ from generic value chain of Porter in terms of grouping activity and the amount of activity. According to Porter (2008), as illustrated in Figure 2 , there are two main activities, namely, internal logistics, operations, external logistics, marketing and sales, as well as service and supporting activities in the form of general administration, human resources, technology research and development, as well as purchasing. The results of the research of value chain of the company's activities consist of the main activities: Purchasing/Procurement (purchasing), materials (logistics), manufacturing (operations), quality control, R\&D (technology research and development), production planning, and sales \& marketing (marketing and sales), as well as supporting activities such as personnel \& general affairs (human resources), information technology, general administration, quality assurance and maintenance.

From both value chain models, it appears that the company has a more complex chain activities. Some characteristics owned by the company compared with the generic value chain of Porter are:

- The activities of Purchasing/Procurement and $\mathrm{R} \& \mathrm{D}$ that is part of the company's main activities, whereas in generic value chain of Porter includes supporting activities.

- The main activities of a company that are not owned by generic value chain activities of Porter, namely, quality control and production planning. In this case, it is possible that two activities are the activities of operations.

- Services in the value chain of Porter are major stand-alone activities, whereas in the value chain of XYZ are part of the Sales and Marketing.

- Supporting activities that are not owned by value chain of Porter but owned by PT XYZ are Information Technology, quality assurance and maintenance. According to Porter, the third activity is likely part of the technology Research and Development system.

\section{Identification of cost driver on value activities}

Cost drivers are factors that change the amount of the total cost. Therefore, the aim at this stage is to identify the activities where the company has a cost advantage of both current and potential cost advantages. To see how much the ratio between raw material costs and total expenses, secondary research and financial data processing from 2010 to 2013 have been conducted. The results of the comparative analysis of material costs, total expense and COGS of companies can be seen in the table below.

Table 1. The comparison of material costs vs total expense

\begin{tabular}{|l|c|c|c|c|}
\hline \multicolumn{1}{|c|}{ Parameter } & $\mathbf{1}^{\text {st }}(\mathbf{x} \mathbf{1 0 0 0})$ & $\left.\mathbf{2}^{\text {nd }} \mathbf{( x 1 0 0 0}\right)$ & $\mathbf{3}^{\text {rd }}(\mathbf{x} \mathbf{1 0 0 0})$ & $\left.\mathbf{4}^{\text {th }} \mathbf{( \mathbf { x } 1 0 0 0}\right)$ \\
\hline Net sales & 189.856 .550 & 246.625 .610 & 235.494 .191 & 294.313 .455 \\
\hline COGS & 147.892 .327 & 196.425 .264 & 199.503 .919 & 241.281 .800 \\
\hline TOTAL expense & 22.434 .580 & 30.208 .551 & 26.933 .106 & 33.086 .675 \\
\hline Margin & 19.529 .642 & 19.991 .796 & 9.057 .165 & 19.944 .980 \\
\hline Raw material costs & 125.457 .747 & 166.216 .713 & 172.570 .813 & 208.195 .125 \\
\hline \% raw material costs & $84.8 \%$ & $84.6 \%$ & $86.5 \%$ & $86.3 \%$ \\
\hline \% total expense & $15.2 \%$ & $15.4 \%$ & $13.5 \%$ & $13.7 \%$ \\
\hline
\end{tabular}

Source : Company Financial Report in the 1st-4th year (processing). 
According to Table 1, we can see that over the years the cost of procurement of raw materials dominates the costs incurred by companies around $85.6 \%$. These are huge costs for the operational company. Therefore, it can be said that the purchase of raw materials is an activity that contains cost driver, because it has the largest cost component in all activities of the company. Total other costs besides the raw material are only accounted for $14.4 \%$ (including all the main and supporting activities other than the purchase cost). By lowering the cost of purchasing, eg., $3 \%$, it will significantly lower the cost of goods sold amounted to $2.6 \%$ in the final product to be sold. Table 1 also shows that the increase in COGS (cost of good sales) of a company is strongly influenced by the rise in raw material (RM cost - raw material cost). Through illustrations of trend graph also shows that other activities combined in the total expense do not show an increase from year to year (stable trend), although the company expand and grow with the addition of a variety of investment and employment.

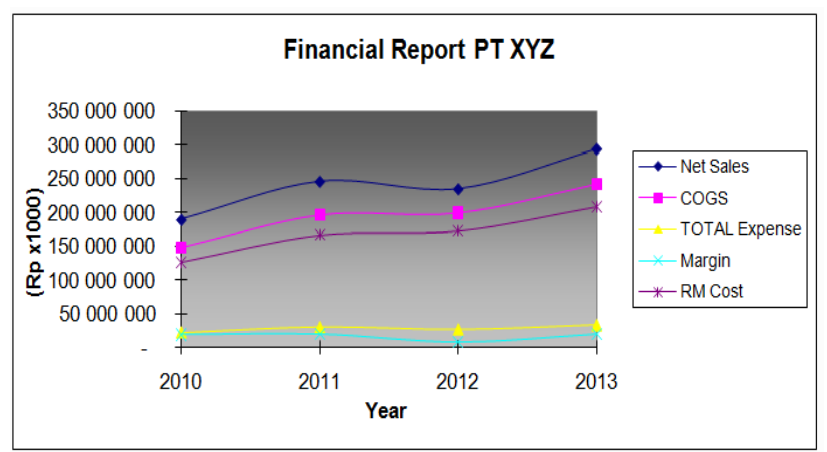

Source : Company Financial Report (processing).

Fig. 4. Trend of company financial report

To learn more about the most influential components of the cost of purchasing raw materials in the value chain, the data collection and information materials of what gives the dominant value is done. Based on the collection and processing of data, the results of the greatest material that contribute to the purchase of natural materials are clove oil. The complete data are as follows:

Table 2. Comparison of purchasing of natural raw material

\begin{tabular}{|c|l|c|c|}
\hline No & Material & Amount (Rp) & $\%$ \\
\hline 1 & Clove Oil & 162.926 .111 .631 .07 & $78.26 \%$ \\
\hline 2 & Patchouli Oil & 25.238 .329 .116 .93 & $12.12 \%$ \\
\hline 3 & Tea Leaf & 3.096 .000 .000 .00 & $1.49 \%$ \\
\hline 4 & Nutmeg Oil & 13.924 .699 .840 .00 & $6.69 \%$ \\
\hline 5 & Vetiver Oil & 1.208 .407 .600 .00 & $0.58 \%$ \\
\hline 6 & Others & 1.801 .576 .812 .00 & $0.87 \%$ \\
\hline $\mathbf{7}$ & Amount & $\mathbf{2 0 8 . 1 9 5 . 1 2 5 . 0 0 0 . 0 0}$ & $\mathbf{1 0 0 . 0 0 \%}$ \\
\hline
\end{tabular}

Source: Report of purchasing natural raw material of a company (processing).
From the bar chart appears that the purchase of natural raw materials such as clove oil amounted to $78.26 \%$ dominates the purchase value followed by Patchouli Oil amounted to $12.12 \%$. Third place is Nutmeg Oil amounted to $6.69 \%$. It is consistent with the Pareto principle stating that $80 \%$ of company's problems are the result of causes that only $20 \%$. Thus, in this case, Clove Oil is a derivative cost driver of purchasing activities.

Through the analysis of the value chain, it can be concluded that the largest component of COGS is the procurement of raw materials $(85.6 \%)$ which is the company's activities with the greatest cost. The dominant raw material is Clove Oil (78.26\%) which is the cost driver of the company's purchasing activities.

\section{Conclusion}

Based on the results of research and discussion, it can be summarized as follows: first, the value chain of a company consists of main and supporting activities. The main activities of a company consist of the activities of supplier, purchasing/ procurement, production planning, manufacturing, materials, quality control (QC), research and development (R\&D), sales and marketing and customer, whereas supporting activities (support) consist of personal and general affair (P \& GA), Information Technology (IT), administration, quality assurance (QA) and maintenance.

Secondly, the activity of purchasing/procurement and R\&D is part of the company's main activity, while at the generic value chain of Porter is included in supporting activities. Third, through the analysis of the value chain, the largest component of COGS is the activity of purchasing of raw materials amounted to $85.6 \%$. Purchasing of raw materials which is the dominant cost driver is the purchase of Clove Oil amounted to $78.26 \%$.

Based on these results, some suggestions proposed are as follows: first, further research with the identification and analysis of internal and external factors is necessary in order to know the internal strengths and weaknesses, opportunities and threats faced by the company; second, the researchers also suggest analysis of competitors' position and the selection of alternative strategies to formulate strategies that can enhance the competitive advantage of companies.

\section{Acknowledgements}

We would like to acknowledge the support of the Doctoral Program of Management Sciences, Universitas Jenderal Soedirman and Universitas Peradaban who has facilitated everything for the publication of this research article. 


\section{References}

1. Bolwig, S., Ponte, S., du Toit, A., Riisgaard, L., Halberg, N. (2010). Integrating poverty and environmental concerns into value-chain analysis: a conceptual framework, Dev. Policy Rev., pp. 28 (2), 173-194.

2. Brigham, Eugene and Houston, Joel. (2004). Fundamentals of Financial Management, Tenth Edition. Published by Thomson, Boston, MA.

3. Bennett, D.J. and Forrester, P.L. (1993). Market-Focused Production Systems: Design and Implementation, Prentice-Hall, London.

4. Fearne, Andrew, Marian Garcia Martinez and Benjamin Dent. (2012). Dimensions of Sustainable Value Chains: Implications for Value Chain Analysis, Supply Chain Management: An International Journal, 17(6), pp. $575-581$.

5. Prajogo, Daniel, Peggy McDermott, Mark Goh. (2008). Impact of value chain activities on quality and innovation, International Journal of Operations \& Production Management, Vol. 28 Iss: 7, pp. 615-637.

6. FAO. (2011). A value chain approach to animal diseases risk management - technical foundations and practical framework for field application, Animal Production and Health Guidelines, No. 4. Rome.

7. Finance \& Controlling. (2012). Financial Report, PT XYZ, Jakarta.

8. Heizer, Jay and Render, Barry. (2008). Operation Management, $9^{\text {th }}$ edition, Pearson education, New Jersey.

9. Hunger, J.D. and Wheelen, T.L. (2001). Strategic Management, Fifth Edition. Addison-Wesley Publishing Company, Inc.

10. Irvine, Richard M. (2015). A Conceptual Study of Value Chain Analysis as a Tool for Assessing a Veterinary Surveillance System for Poultry in Great Britain, Agricultural Systems, 135, pp. 143-58.

11. Jones, D. and Womack, J. (2002). Seeing the Whole - Mapping the Extended Value Stream, Lean Enterprise Institute, Cambridge, MA.

12. Lee, C.W., Kwon, I.W. and Severance, D. (2007). Relationship between supply chain performance and degree of linkage among supplier, internal integration and customer, Supply Chain Management: An International Journal, Vol. 12 No. 6, pp. 44-52.

13. Mangan, J., Lalwani, C., Butcher, T., Javadpour, R. (2012). Supply chain strategies. In: Mangan, J., Lalwani, C., Butcher, T., Javadpour, R. (Eds.), Global Logistics and Supply Chain Management, second ed. John Wiley \& Sons Ltd, Chichester, UK, pp. 59-77.

14. Ministry of Agriculture. (2012). The Indonesian Forestry Statistics 2008-2010, cloves, Secretariat of the Directorate General of Plantation, Jakarta.

15. Ouzrout, Yacine et. All. (2009). Supply chain management analysis: a simulation approach to the Value Chain Operations Reference (VCOR) model, International Journal of Value Chain Management, 3(3), pp. 263-287

16. Pearce, John and Robinson, Richard. (2007). Strategic Management: Formulation, Implementation, and Control, Richard D Irwin, NV, USA.

17. Porter, M.E. (1985). Competitive Strategy. Macmillan Publishing Co., Inc., USA.

18. Porter, M.E. (2008). Competitive Advantage: creating and sustaining performance. Amazon Digital Services, Incorporated.

19. Rushton, J. (2009). Tools that go beyond the enterprise, farm or business level: investigating markets, market trends and assessing public investments in the livestock sector. In: Rushton, J. (Ed.), The Economics of Animal Health and Production. CABI Publishing, Wallingford, UK, pp. 116-135.

20. Rushton, J., Leonard, D.K. (2009). The new institutional economics and the assessment of animal disease control. In: Rushton, J. (Ed.), The Economics of Animal Health and Production. CABI Publishing, Wallingford, UK, pp. 144-148.

21. Soosay, C., A. Fearne and B. Dent. (2012). Sustainable Value Chain Analysis - A Case Study Of Oxford Landing From 'Vine to Dine', Supply Chain Management: An International Journal, 17(1), pp. 68-77. Retrieved from: http://dx.doi.org/10.1108/1359854121121221.

22. Taylor, D.H. (2005). Value chain analysis: an approach to supply chain improvement in agri-food chains, International Journal of Physical Distribution \& Logistics Management, Vol. 35 Nos 9/10, pp. 744-762.

23. Walters, David and Mark Rainbird (2004), The demand chain as an integral component of the value chain, Journal of Consumer Marketing, Vol. 21 Iss: 7, pp. 465-475.

24. Yin, R. (1994). Case study research: Design and methods . Beverly Hills.

25. Zokaei, A. Keivan and David W. Simons. (2006). Value Chain Analysis in Consumer Focus Improvement: A Case Study of the UK Red Meat Industry, The International Journal of Logistics Management, 17(2), pp. 141-62. 